\title{
Performance and nutritional evaluation of beef cattle raised on pasture, castrated at different ages, with and without supplementation ${ }^{1}$
}

\author{
Anilza Andréia da Rocha ${ }^{2}$, Mário Fonseca Paulino ${ }^{3}$, Henrique Jorge Fernandes ${ }^{4}$, \\ Lívia Vieira de Barros², Sidnei Antonio Lopes ${ }^{2}$, Leandro Galon ${ }^{5}$, Aline Gomes da Silva², \\ Daniel Mageste de Almeida ${ }^{2}$
}

\footnotetext{
1 Project financed by Fapemig.

2 Universidade Federal de Viçosa.

${ }^{3}$ Universidade Federal de Viçosa. Researcher INCT-CA.

4 Universidade Estadual de Mato Grosso do Sul.

${ }^{5}$ Universidade Federal do Pampa.
}

ABSTRACT - The objective of this study was to evaluate performance and nutritional traits of beef cattle raised on pastures, castrated at different ages, with and without supplementation. Forty-four crossbred young bulls with predominance of Zebu breed at initial average age of $120 \pm 30$ days were used in the experiment. Animals were distributed in a completely randomized design in a factorial arrangement with four ages of castration and two supplementation systems. The animals were distributed into four groups and placed on Brachiaria decumbens Stapf pastures, where they were fed concentrate supplementation or mineral salt ad libtum (control). Animals were castrated at 120, 240 and 360 days of age with average body weight of 115, 175 and $276 \mathrm{~kg}$, castrated or not, in each supplementation group. Concentrate supplement composition and the amount supplied to the animals varied according to the time of the year and development phase of the animals. Trials were carried out to evaluate nutritional variables in each of the following phases: suckling, growth in the dry season and growth in the dry/rainy transition season. Concentrate supplementation improved the use of pasture, although it may have caused substitutive effect in all seasons evaluated. Castration of the animals before the dry season impaired animal development until the following dry/rainy transition season, especially when carried out during weaning. Concentrate supply may reduce some effects of this stress.

Key Words: castration, digestibility, intake, supplementation

\section{Introduction}

The slow growth of calves from birth to weaning and from weaning to yearling has contributed to poor performance observed in production systems for beef cattle. In this context, supplementary feeding for suckling calves under the creep feeding system takes great importance.

To be considered effective, a program of supplementation on pasture production system has to add nutrients to the diet of animals and not to replace nutrients that would be present naturally in the ingested pasture. From this point of view, the use of concentrate supplements can make the system economically viable inasmuch as it corrects nutritional deficiencies and maintains forage intake by the animal high.

Castration is a management practice that can be used in beef cattle on pasture. The main advantages of this practice are the easier management, since it make animals more docile, and improvement on carcass quality, which contributes to its acceptance in the market, especially in the meatpacking industry.
Systems of beef cattle production in Brazil have been intensifying. In this new perspective, it is crucial to determine the best age to castration and to understand their effects and their interactions with the nutritional aspects of animals.

The objective of this study was to evaluate the effect of supplementation and castration at different ages on performance and nutritional characteristics of beef cattle produced in the pasture/supplement system.

\section{Material and Methods}

This experiment was carried out in Setor de Bovinocultura de Corte in Departamento de Zootecnia at Universidade Federal de Viçosa, from March to December 2008.

The work started with 44 crossbred male calves, at least $50 \%$ Nellore breed, at average initial age of $120 \pm 30.1$ days and with $115.3 \pm 1.97 \mathrm{~kg}$ body weight, all fed by their respective dams. Treatment against ecto and endoparasites was carried out at the beginning and whenever necessary during the experimental period. 
The experimental area consisted of five paddocks of 6.8 ha each, formed with Brachiaria decumbens Stapf, provided with drinkers and covered creep feeding for calves. The animals were subjected to seven days of adaptation to the experimental area and diet, and subsequently weighed at the beginning of the experiment and every 28 days, always in the morning. The plots were rotated among paddocks every seven days in order to reduce possible differences between paddocks.

Then, animals were randomly distributed into two groups, to which assessed supplements (concentrate supplementation or mineral mixture) were added. In each group of supplementation, animals were castrated at 120 , 240 and 360 days of age, or just not castrated.

The supplements were provided daily around 10:00 a.m. The composition of the concentrate supplement and quantity provided varied according to period of the year and stage of life of animals (Table 1).

In the suckling phase, from March to June, the supplements were supplied at the amount of $750 \mathrm{~g} / \mathrm{animal} / \mathrm{day}$.

In the growth phase, during the dry season, the supplements were supplied at the quantity of 1,500 g/animal/ day. In the growth phase, during the dry/rainy transition season, the supplements were supplied at the quantity of $1,700 \mathrm{~g} /$ animal/day.

Some animals were slaughtered during the experiment period, according to a two-step protocol. At the time of weaning, in the beginning of the dry season, eight animals: four castrated at 120 days of age (two animals of the treatment supplemented with mineral mixture and two animals of the treatment supplemented with concentrate) and four non-castrated animals (also two animals of the treatment supplemented with mineral mixture and two animals of the treatment supplemented with concentrate). Slaughter was carried out in October, at the beginning of the dry/rainy season when twelve animals were slaughtered, two animals castrated at 120 days of age (one animal from the mineral mixture treatment and one animal from the supplemented with concentrate treatment, four animals castrated at 240 days of age (two animals of the mineral mixture treatment and two animals of the supplemented with concentrate treatment) and six non-castrated animals (three animals of the mineral mixture treatment and three animals of the supplemented with concentrate treatment).

In the suckling phase, milk intake of all calves was measured every 28 days by the difference between the weight of the calf obtained after and before a 30-minute breast-feeding. Before weighing, the calves were separated from their dams for 12 hours. Daily intake of milk (24 hours) was calculated by the difference in weight of calves multiplied by two.

Forage was harvested by cuttings at $5 \mathrm{~cm}$ from the ground in four areas limited by $0.5 \times 0.5-\mathrm{m}$ metallic square, chosen at random from each experimental paddock to evaluate forage availability.

A trial to evaluate intake and diet digestibility was carried out in each one of the phases to evaluate the nutritional variables. The same experimental animals (not slaughtered) and the same area where they were housed were used in each phase.

To estimate the fecal excretion, enriched and purified lignin (LIPE) ${ }^{\circledR}$ (Rodriguez et al., 2006) was used as external

Table 1 - Composition of concentrate supplements, pasture and milk intake of animals at the different phases

\begin{tabular}{|c|c|c|c|c|c|c|c|}
\hline \multirow[t]{2}{*}{ Item } & \multicolumn{3}{|c|}{ Suckling phase } & \multicolumn{2}{|c|}{$\begin{array}{l}\text { Growth phase, } \\
\text { dry season }\end{array}$} & \multicolumn{2}{|c|}{$\begin{array}{l}\text { Growth phase, } \\
\text { dry/rainy transition season }\end{array}$} \\
\hline & Supplement & Pasture $^{2}$ & Milk & Supplement & Pasture $^{1}$ & Supplement & Pasture $^{1}$ \\
\hline Corn + sorghum & 62.0 & & & 43.2 & & 53.2 & \\
\hline Soybean meal & 32.7 & & & 55.1 & & 50.5 & \\
\hline Dry matter (DM) & 87.2 & $22.1 \pm 2.45$ & 13.1 & 87.1 & $21.8 \pm 2.24$ & 87.9 & $24.6 \pm 2.34$ \\
\hline Organic matter & 93.9 & $91.48 \pm 0.21$ & 90.0 & 80.9 & $91.8 \pm 0.15$ & 92.0 & $92.43 \pm 0.33$ \\
\hline Crude protein & 19.9 & $9.31 \pm 0.30$ & 24.9 & 28.9 & $8.19 \pm 0.27$ & 22.9 & $9.3 \pm 0.23$ \\
\hline NDFap & 10.0 & $60.75 \pm 1.10$ & 0.0 & 11.5 & $69.12 \pm 1.04$ & 10.4 & $71.56 \pm 1.06$ \\
\hline Indigestible neutral detergent fiber & 1.6 & $16.7 \pm 1.61$ & 0.0 & 1.6 & $18.3 \pm 1.10$ & 1.6 & $20.25 \pm 1.62$ \\
\hline
\end{tabular}

NFap = neutral detergent fiber correct for ash and protein.

${ }^{1}$ Obtained from manual grazing simulation. The average daily gain (ADG) was calculated as the difference between the initial and final body weight of animals in each evaluated phase divided by the number of days of the stage. Pasture sampling for evaluation of forage quality was conducted via manual grazing simulation at every 28 days. There was a total of 10 evaluations, four evaluations in the suckling phase, three in the growth during dry season and three evaluations in growth during the dry/ rainy transition season.

${ }^{2}$ Expressed as \%DM, except for DM (expressed as \% natural matter - NM). 
marker, and titanium dioxide $\left(\mathrm{TiO}_{2}\right)$ was used as supplement intake marker and indigestible neutral detergent fiber (iNDF) was used as internal marker for dry matter total intake.

During the trials, on the first nine days, titanium dioxide was mixed with supplement at the quantity of $1 \%$ of supplement per day immediately before supplement supply to allow measurement of individual intake of the supplement (Titgemeyer et al., 2001). Capsules with $250 \mathrm{mg}$ of LIPE ${ }^{\circledR}$ were applied in the animals by esophageal probe on days seven, eight and nine.

Fecal samples were collected from the 8th to the 10th day at different times (2:00 p.m., 10:00 a.m., and 6:00 a.m.) and each time collected in one day. After grinding the samples, a composite sample of feces per animal was made in each trial (including the three days of collection), which were stored in properly identified glass jars.

On the last day of the trial for nutritional variables evaluation, samples of "spot" urine $(10 \mathrm{~mL})$ were collected from spontaneous urination and blood samples were collected directly from the jugular vein at 2:00 p.m. (4 hours after concentrate supplement supply). After collection, samples of urine were diluted in $40 \mathrm{~mL}$ of $\mathrm{H}_{2} \mathrm{SO}_{4}(0.036 \mathrm{~N})$, (Valadares et al., 1999), which was for quantification of urinary concentrations of creatinine and total nitrogen.

Blood samples were collected simultaneously to urinary sampling using vacuum tubes with gel and coagulation accelerator gel (BD Vacuntainer ${ }^{\circledR}$ SST II Advance). The blood samples were immediately sent to be centrifuged (20 min at $7,200 \mathrm{x} \mathrm{g}$ ) and the serum was frozen at $-20{ }^{\circ} \mathrm{C}$ for further evaluation of the level of urea serum. The blood serum samples were analyzed for concentrations of urea, according to the enzymatic-colorimetric method $\left(\operatorname{Human}{ }^{\circledR}\right)$.

Samples of feces were further analyzed for concentrations of LIPE ${ }^{\circledR}$. They were also analyzed for dry matter, crude protein, ether extract, neutral detergent fiber corrected for ash and protein and ash.

These samples were also quantified for the levels of iNDF by in situ rumen incubation procedure for 240 hours (Casali et al., 2008). Fecal excretion was estimated using the technique described by Rodriguez et al. (2006).

Estimate of individual intake of the supplement was obtained by the following equation: IISup $=(\mathrm{FE} \times \mathrm{CMF}) / \mathrm{II}$, in which IISup = individual intake of the supplement (kg/day); $\mathrm{CMF}=$ concentration of the marker in the feces of the animal $(\mathrm{kg} / \mathrm{kg}) ; \mathrm{II}=$ concentration of the marker in the supplement $(\mathrm{kg} / \mathrm{kg}) ; \mathrm{FE}=$ fecal excretion ( $\mathrm{kg} /$ day)

Dry matter total intake was estimated by using iNDF as internal marker, by using the following equation: DMI $(\mathrm{kg} /$ day $)=\{[(\mathrm{FE} \times \mathrm{CIF})-(\mathrm{MS} \times \mathrm{SDMI})] / \mathrm{CMFO}\}+\mathrm{SDMI}$, in which $\mathrm{CMF}=$ concentration of the marker in the feces $(\mathrm{kg} / \mathrm{kg})$;
$\mathrm{CMFO}=$ concentration of the marker in the forage $(\mathrm{kg} / \mathrm{kg})$; SDMI = supplement dry matter intake ( $\mathrm{kg} /$ day); FE = fecal extraction (kg/day); and MS = concentration of marker in the supplement $(\mathrm{kg} / \mathrm{kg})$.

Estimate of milk dry matter daily intake was included in the suckling phase to calculate DMI.

Urine samples were analyzed for levels of creatinine according to the modified method of Jaffé(Human ${ }^{\circledR}$ ), and total nitrogen was analyzed according the method of Kjeldhal (Silva \& Queiroz, 2002).

Microbial protein synthesis was estimated by daily excretion of purine derivatives in the urine. Urinary volume was calculated by using daily creatinine excretion (CE) as control, by adopting the equation proposed by Chizzotti et al. (2006). Allantoin and uric acid were analyzed by the colorimetric method, according to the method of Fujihara et al. (1987). Total excretion of purine derivatives was calculated by summing quantities of allantoin and uric acid excreted in the urine.

Absorbed purines (Y, mmol/day) were calculated from the excretion of purine derivatives ( $\mathrm{X}, \mathrm{mmol} /$ day), through the equation: $\mathrm{Y}=\left(\mathrm{X}-0.385 \times \mathrm{BW}^{0.75}\right) / 0.85$, in which $0.85=$ recovery of absorbed purines as purine derivatives; $0.385 \times$ $\mathrm{BW}^{0.75}=$ endogenous contribution for purine excretion (Verbic et al.,1990); BW = body weight.

Ruminal synthesis of nitrogen compounds (Z, g Nmic/day), was calculated in function of (Y, mmol/day), by using the equation described by Chen \& Gomes (1992), except for $\mathrm{N}$ purines: $\mathrm{N}$ total bacteria ratio, in which the value of 0.134 was used as suggested by Valadares et al. (1999): $\mathrm{Z}=70 \times \mathrm{Y} /(0.83 \times 0.134 \times 1000)$, in which $70=$ contend of purine $\mathrm{N}(\mathrm{mg} \mathrm{N} / \mathrm{mol}) ; 0.134=\mathrm{N}$ purines: $\mathrm{N}$ total in bacteria ratio; and $0.83=$ bacterial purine digestibility.

The experiment was analyzed in a completely randomized design in a $4 \times 2$ factorial design considering the effect of four seasons of castration $(120 \mathrm{~d}, 240 \mathrm{~d}, 360 \mathrm{~d}$ and noncastrated), nested within each one of the two supplementation systems (mineral mixture or concentrate supplementation), and comparisons between means of treatments carried out by the DMS test $(\alpha=0.05)$.

\section{Results and Discussion}

The average availability of total dry matter of forage was $6.7 \mathrm{t} / \mathrm{ha}$ in suckling phase, during the dry/rainy transition season; $3.7 \mathrm{t} / \mathrm{ha}$ during the dry season, and $5.1 \mathrm{t} / \mathrm{ha}$ during the dry/rainy transition season.

There was no significant difference $(\mathrm{P}>0.05)$ for milk production of cows in the different treatments evaluated (Table 2). Similar results were obtained by Valente (2009), 
who found no differences in milk production between cows with their calves with or without supplemented.

On the other hand, there are literature reports that supplementation of calves until weaning may reduce milk production due to reduction of suckling stimuli (Fordyce et al., 1996).

The lack of difference in milk production of dams observed in this study implies that these dams did not affect the observed performance of the animals until weaning.

Supplementation with concentrate affected $(\mathrm{P}<0.05)$ pasture intake, non-fibrous carbohydrates intake, dry matter digestibility coefficient, neutral detergent fiber coefficient of digestibility and total digestible nutrient content in the diet consumed by the animals during the suckling phase, increasing these coefficients (Table 3).

The difference found in pasture intake and neutral detergent fiber intake (expressed in $\mathrm{g} / \mathrm{g} \mathrm{BW}$ ) show that there was a substitutive effect, because the results of pasture intake by the animals that received mineral supplementation was higher than that of those fed concentrate supplementation.

The average intake of concentrate at this phase was around $2.2 \mathrm{~g} / \mathrm{kg}$ of body weight, whereas the supplemented animals reduced their pasture intake by $3.4 \mathrm{~g} / \mathrm{kg}$ of body weight. As milk consumption did not vary between treatments, this more than proportional substitute effect may be associated with a disorder in the metabolic conditions due to high ingestion of non-fibrous carbohydrate by supplemented animals (Paulino et al., 2003; Fernandes, 2009).

The greater intake relative to neutral detergent fiber by the animals which were not fed concentrate supplement is directly linked to increased consumption of pasture by these animals (Fernandes, 2009).

As concentrate intake was about $10 \%$ of total DM ingested daily by the animals, improvement of about 3.9 percentage points in the digestibility of the diet cannot be attributed only to a greater digestibility of this concentrate in relation to pasture. Therefore, the improvement found in this study can be attributed to better digestibility of the pasture by animals supplemented with concentrates. Zamperlini (2008) highlighted the greater rumen development of calves supplemented with concentrates, which may lead to a possible increase in the pasture digestibility capacity of these animals, explaining these results.

Castration of animals, in turn, reduced the intake of concentrate at this phase (Table 3). This may be associated with the stress caused by castration. The stressed animals may have had their behavior affected, showing less impetus to consume the concentrate supplement. The substitution effect, as discussed here, may have masked this effect of reduced intake due to castration, with regard to pasture intake. As noncastrated animals consumed more concentrate, a greater replacement effect was expected, which would cause greater reduction in pasture intake than in castrated animals. Thus, as observed in this study, pasture intake would be similar for both. However, it must be highlighted that this lower intake of concentrate did not influence the total dry matter daily intake. This is probably due to the reduction of the substitutive effect of concentrate supplementation.

Concentrate supplementation affected $(\mathrm{P}<0.05)$ average daily gain, urinary nitrogen excretion and urea nitrogen in serum in the suckling phase. Animals fed this supplementation had higher values for these variables in relation to control. No effects of supplementation were found on production or efficiency of ruminal microbial synthesis (Table 4).

The castration affected $(\mathrm{P}<0.05)$ only the average daily gain of animals that received no concentrate supplementation. The lower weight gain in castrated animals may be attributed to the stress of castration or to a difference in the composition of weight gain of these animals, with greater priority given to the deposition of adipose tissue (Berg \& Butterfiled, 1976). However, because concentrate supplementation compensated part of this effect of castration on weight gain, the hypothesis of stress being responsible for the lower performance of these animals is reinforced. Thus, the supply of concentrate at this phase might have reduced the effects of stress.

Concentrate supplementation increased intakes of crude protein, non-fibrous carbohydrates and total digestible nutrients in the growing phase during the dry season (Table 5). Because protein is the most limiting nutrient in pastures at this time of the year, the main objective of concentrate supplementation was to correct exactly this deficiency in the diet of animals, which could be observed by the greater intake of crude protein.

Table 2 - Least square means of milk yield of cows, dams of the calves participating in the experiment

\begin{tabular}{lccccccc}
\hline \multirow{2}{*}{ Item } & \multicolumn{2}{c}{ Supplementation } & & \multicolumn{2}{c}{ Age at castration } & \multicolumn{2}{c}{ CV (\%) } \\
\cline { 2 - 3 } & Mineral mixture & Concentrate & & Non-castrated & 120 days of age \\
\hline Milk yield, kg/d & 5.88 & 6.15 & & 6.12 & 5.92 & 25.9 \\
\hline
\end{tabular}

$\mathrm{CV}$ - coefficient of variation. 

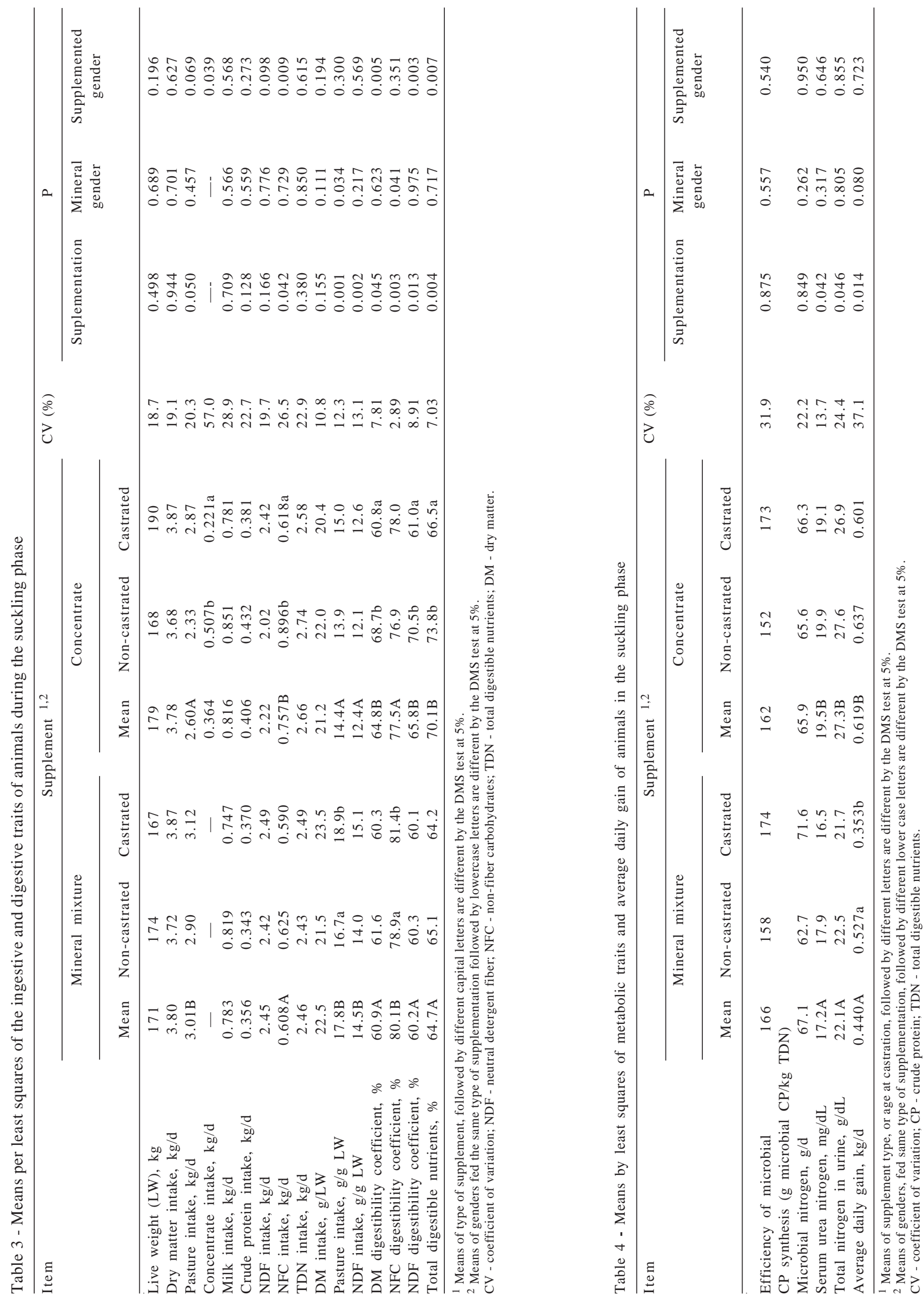

R. Bras. Zootec., v.41, n.4, p.1016-1024, 2012 
The increase in non-fibrous carbohydrates intake by animals fed concentrates was also expected, as discussed in the suckling phase. The increase found in the consumption of total digestible nutrients, in turn, points to an increase in the digestibility of pasture ingested by animals (Paulino et al., 2004). The approximately $900 \mathrm{~g}$ more total digestible nutrients consumed daily by animals supplemented with concentrates could not come only from about $759 \mathrm{~g}$ of concentrate consumed during this period.

The reduction in the consumption of pasture expressed in relative terms ( $\mathrm{g} / \mathrm{kg} \mathrm{BW}$ ) in the animals supplemented with concentrate may be explained by the substitute effect of concentrate intake, also already discussed. However, in this example, the substitution effect evaluated by the relative consumption of pasture may have been close to $100 \%$ of total concentrate ingested.

Overall, regardless of the age at which castration was done, it did not affect digestive or ingestive characteristics of animals during growth phase in the dry season (Table 5).

On the other hand, the supply of concentrate supplement increased the digestibility of all dietary components during this phase. This result may be a combination of greater digestibility of the concentrate in relation to pasture, and improvement of digestibility of pasture due to better rumen conditions of the animals (Paulino et al., 2004).

Although castration of animals did not affect the digestibility at this phase (Table 5), it reduced the synthesis of microbial nitrogen and urinary excretion of nitrogen in animals castrated at shorter time (at 240 days of age at the start of the dry season) (Table 6). This may be explained by the recent stress to which these animals had been exposed, which could cause metabolic changes that may interfere with rumen fermentation. The fact that this time of castration coincided with the time of weaning, and therefore adaptation of the gastrointestinal tract to an exclusively solid diet, along with the simultaneous onset of the dry period, and worsening of pasture conditions might have aggravated the effect of this stress.

The improvement in average daily gain and in the level of urea in the serum of animals supplemented with concentrates during the dry season are a direct result of better ingestive and digestive conditions of these animals.

Supply of concentrate supplement increased only the absolute intake of non-fibrous carbohydrates of animals during the dry/rainy transition season (Table 7). Because in this phase, animals supplemented with concentrates had a greater weight ( $\mathrm{P}<0.05$ ), direct comparison of consumption values cannot be done, which may have been influenced by the size of the animals (Fernandes, 2009).

The comparison of the relative consumption of pasture during this period showed, once more, the occurrence of 

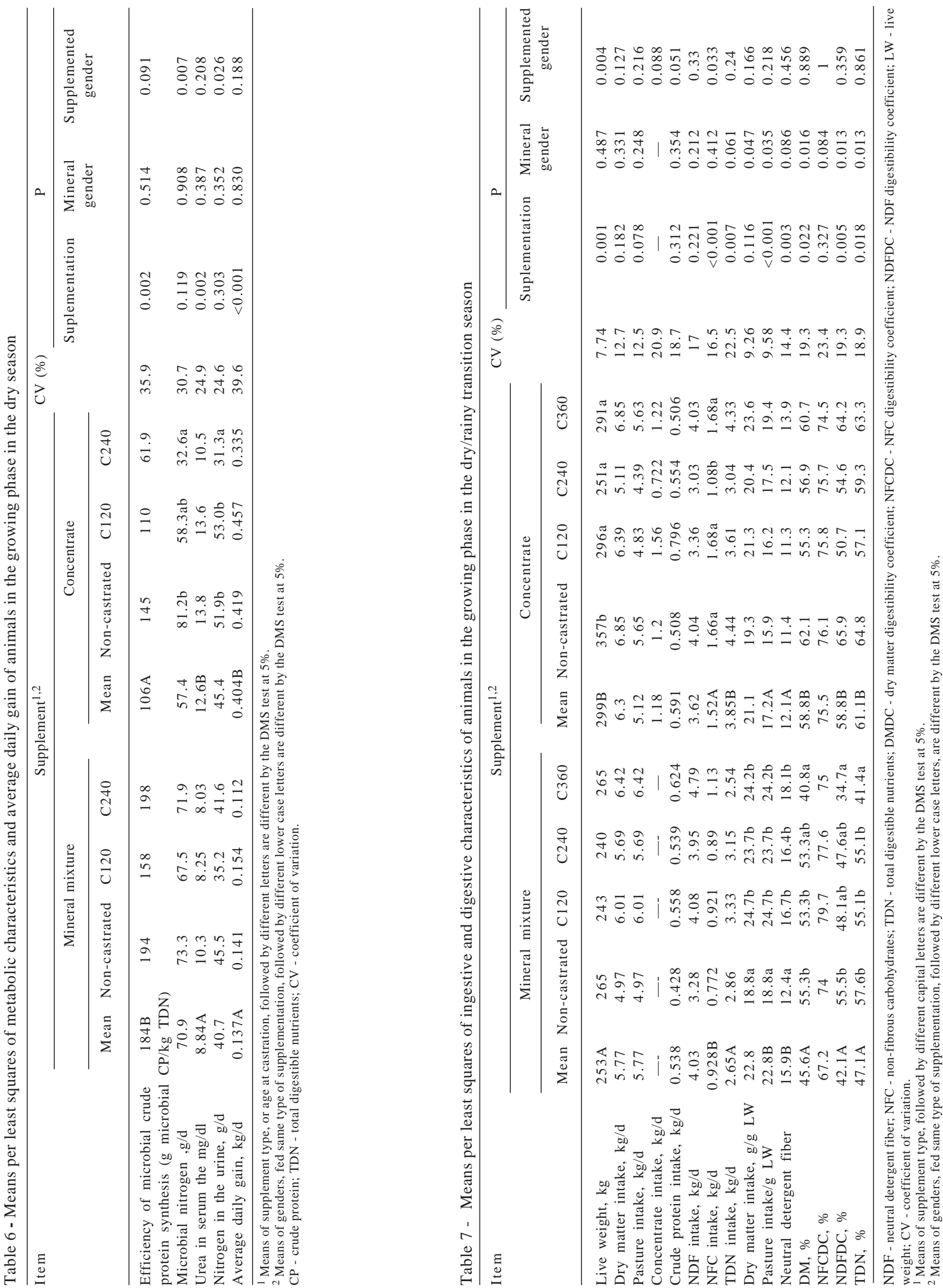
substitutive effect of concentrate intake. The lowest daily relative intake of NDF by animals supplemented with concentrate during this period is also directly linked to the reduction in pasture intake.

When the effect of castration at different ages on the ingestive characteristics during this period was evaluated, the numerical differences in consumption appear to be the main responsible for the differences found in non-fibrous carbohydrates intake.

The consequences of the delay in the rumen development of animals supplemented with concentrate due to the stress of castration and to the dry period simultaneously might be reflected until the dry/rainy transition period, about six months after the castration of these animals. The lower $(\mathrm{P}<0.05)$ live weight of animals at this phase evidence this effect.

However, for animals supplemented only with minerals, the nutritional restriction caused by the dry season did not allow them to express their capacity for development at this phase, masking the castration stress effect before the dry period on live weight of animals in the dry/rainy transition season. Despite being numerically smaller, the weight of castrated animals at 120 or 240 days of age did not differ significantly from those not castrated, or castrated only at the end of the dry period. However, the delay in development caused by the stress of early castration was also evidenced in less weight gain of these animals (castrated at 120 or 240 days of age) in the dry/rainy transition phase (Table 8). The lower capacity of these animals to use the improved nutritional conditions after the dry season to recover the weight they should have gained may be associated with a lower rumen development of these animals.

The lack of difference found in the analysis of the relative consumption (expressed as $\mathrm{g} / \mathrm{kg} \mathrm{BW}$ ) showed that the lower capacity of animals castrated at 240 days of ingesting the concentrate supplement was linked to their smaller size.

Nevertheless, in animals which were not fed concentrate, in this dry/rainy transition season, a general castration effect was found, regardless of the age when it was performed, increasing relative intake of pasture by the animals. This increased consumption of castrated animals not supplemented with concentrate can explain the lower digestibility in the pasture nutrients found in these animals. Higher intake would lead to higher rates of passage, which clearly reduces the digestibility of the diet.

The digestibility of the diet was also higher for animals fed concentrate supplement at this phase. The greater availability of energy in the concentrate supplement in relation to pasture may have contributed to this result, in addition to improving the digestibility of pasture.

The highest level of nitrogen in urine found in animals supplemented at this time of the year shows a lower use efficiency of metabolic $\mathrm{N}$ available for these animals (Table 8).

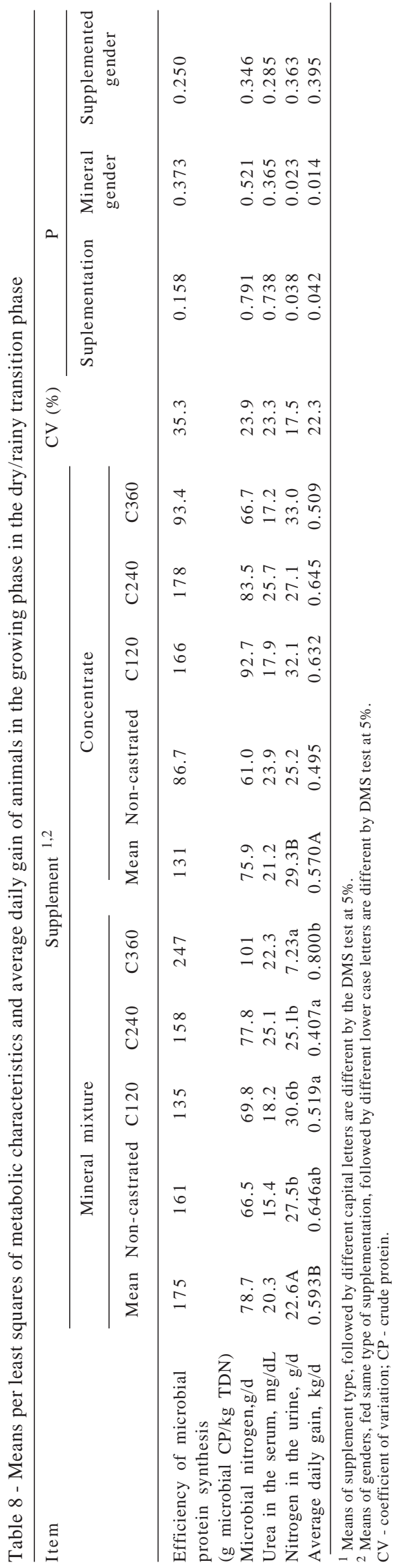

R. Bras. Zootec., v.41, n.4, p.1016-1024, 2012 
The animals fed concentrate supplementation had a greater weight gain when castrated at 360 days of age or when non-castrated if compared with animals or castrated at 120 and 240 days of age. According to these authors, males non-castrated or castrated later grow about 10 to $20 \%$ faster than castrated males, under good feeding and management conditions.

It is well established that close to the finishing phase, castrated males present lower performance (rate of weight gain and carcass) and higher feed conversion than bulls (Kirkland et al., 2005). Concentrate supplementation or castration did not affect other metabolic evaluated at this phase (Table 8).

\section{Conclusions}

Concentrate supplementation improves utilization of the pasture, despite causing a replacement effect. Castration of animals before the start of the dry season hinders the development of animals during at least until the following dry/ rainy transition season, especially when performed at the time of weaning, close to 240 days of life. The supply of concentrate may reduce some effects of stress. Castration in animals at 12 months of age can be recommended.

\section{References}

BERG, R.T.; BUTTERFIELD, R.M. New concepts of cattle growth.Sydney: Sydney University Press, 1976. 240p.

CASALI, A.O.; DETMANN, E.; VALADARES FILHO, S.C. et al. Influência do tempo de incubação e do tamanho de partículas sobre os teores de compostos indigestíveis em alimentos e fezes bovinas obtidos por procedimentos in situ. Revista Brasileira de Zootecnia, v.37, n.2, p.335-342, 2008.

CHEN, X.B.; GOMES, M.J. Estimation of microbial protein supply to sheep and cattle based on urinary excretion of purine derivatives - an overview of technical details (Occasional publication). International Feed Resources Unit. Bucksburnd, Aberdeen: Rowett Research Institute, 1992. 21p.

CHIZZOTTI, M.L.; VALADARES FILHO, S.C.; VALADARES, R.F.D. Consumo, digestibilidade e excreção de uréia e derivados de purinas em novilhas de diferentes pesos. Revista Brasileira de Zootecnia, v.35, n.4, p.1813-1821, 2006.
FERNANDES, H.J. Estudo do crescimento de tourinhos em pastejo recebendo suplementação concentrada com diferentes perfis protéicos. 2009. 288f. Tese (Doutorado em Zootecnia) Universidade Federal de Viçosa, Viçosa-MG.

FORDYCE, J.; COOPER, N.J.; KENDALL, I.E. et al. Creep feeding and prepartum supplementation effects on growth and fertility of Brahman-cross cattle in the dry tropics. Australian Journal of Experimental Agriculture, v.36, n.4, p.389-395, 1996.

FUJIHARA, T.; ØRSKOV, E.R.; REEDS, P.J. et al. The effect of protein infusion on urinary excretion of purine derivatives in ruminants nourished by intragastric nutrition. The Journal of Agricultural Science, v.109, n.1, p.7-12, 1987.

KIRKLAND, R.M.; STEEN, R.W.J.; PATTERSON, D.C. et al. Effects of slaughter weight on production traits in Holstein-Friesian bulls. In: ANNUAL MEETING OF THE BRITISH SOCIETY OF ANIMAL SCIENCE, 2005, York. Proceedings... York: British Society of Animal Science, 2005. p.1-2.

PAULINO, M.F.; ACEDO, T.S.; SALES, M.F.L. et al. Suplementação como estratégia de manejo das pastagens. In: VOLUMOSOS NA PRODUÇÃO DE RUMINANTES: Valor alimentício de forragens, 2003, Jaboticabal. Anais... Jaboticabal, 2003. p.87-100.

PAULINO, M.F.; FIGUEIREDO, D.M.; MORAES, E.H.B.K. et al. Suplementação de bovinos em pastagens: uma visão sistêmica. In: SIMCORTE - SIMPÓSIO DE PRODUÇÃO DE GADO DE CORTE, 4., 2004, Viçosa-MG. Anais... Viçosa: DZO/UFV, 2004. p.93-144.

RODRÍGUEZ, N.M.; SIMÕES SALIBA, E.O.; GUIMARÃES JUNIOR, R. Uso de indicadores para estimativa de consumo a pasto e digestibilidade. In: REUNIÃO ANUAL DA SOCIEDADE BRASILEIRA DE ZOOTECNIA, 43., 2006, João Pessoa. Anais... JoãoPessoa: SBZ, 2006. p.323-352.

SILVA, D.J.; QUEIROZ, A.C. Análise de alimentos (métodos químicos e biológicos). Viçosa, MG: Universidade Federal de Viçosa, 2002. 235p.

TITGEMEYER, E.C.; ARMENDARIZ, C.K.; BINDEL, D.J. et al. Evaluation of titanium dioxide as a digestibility marker for cattle. Journal of Animal Science, v.79, p.1059-1063, 2001.

VALADARES, R.F.D.; BRODERICK, G.A.; VALADARES FILHO, S.C. et al. Effect of replacing alfalfa silage with high moisture corn on ruminal protein synthesis estimated from excretion of total purine derivatives. Journal of Dairy Science, v.82, n.11, p.2686-2696, 1999.

VALENTE, E.E.L. Suplementação de bezerras de corte lactentes e em recria e parâmetros nutricionais de vacas de corte em pastejo. 2009. 63f. Dissertação (Mestrado em Zootecnia) Universidade Federal de Viçosa, Viçosa, MG.

VERBIC, J.; CHEN, X.B.; MACLEOD, N.A. et al. Excretion of purine derivatives by ruminants. Effects of microbial nucleic acid infusion on purine derivative excretion by steers. Journal of Agricultural Science, v.114, n.3, p.243-248, 1990.

ZAMPERLINI, B. Concentração de proteína e cronologia de fornecimento de suplementos para bezerros lactentes sob sistema de creep feeding. 2008. 68f. Tese (Doutorado em Zootecnia) - Universidade Federal de Viçosa, Viçosa-MG. 